\title{
Efficiency of Elemental Sulfur and Phosphorus Fertilizer in Enhancing Soybean (Glycine max L.) Growth and Yield in a Clayey Soil
}

\author{
Maha Mohamed El- Sayed Ali \\ Department of Soils and Water, Faculty of Agriculture, Benha University, Moshtohor, \\ Toukh, Kalyoubia, 13736, Egypt.
}

\begin{abstract}
A FIELD experiment was conducted during the summer season of 2013 in the farm of Faculty of Agriculture, Benha University, Egypt. Sixteen treatments with three replicates were performed and resulted from the combination of four rates of the elemental sulfur $(\mathrm{S} 0=\mathrm{zero}$, $\mathrm{S} 1=119, \mathrm{~S} 2=238$ and $\left.\mathrm{S} 3=357 \mathrm{~kg} \mathrm{~S}^{-1}\right)$ and four rates of $\mathrm{P}(\mathrm{P} 0=0, \mathrm{P} 1=238, \mathrm{P} 2=476$ and $\mathrm{P} 3=714$ $\mathrm{kg}$ superphosphate $\left.\mathrm{ha}^{-1}\right)$. Application of $\mathrm{S}$ at all used $\mathrm{P}$ rates increased branch and pod numbers, nutrients concentrations, and protein and oil contents of soybean. The highest values of the above-mentioned parameters were found at addition of $357 \mathrm{~kg} \mathrm{~S}^{-1}$ in the presence of 714 $\mathrm{kg}$ superphosphate ha- ${ }^{-1}$, which were statistically similar to those at $238 \mathrm{~kg} \mathrm{~S}^{-1}$ with $476 \mathrm{~kg}$ superphosphate $\mathrm{ha}^{-1}$. Straw and seed yields of soybean showed the same performance under 238 $\mathrm{kg} \mathrm{S} \mathrm{ha}^{-1}$ and $357 \mathrm{~kg} \mathrm{Sha}^{-1}$ in the presence of all applied doses of superphosphate. So, application of $238 \mathrm{~kg} \mathrm{~S} \mathrm{ha}^{-1}$ and $476 \mathrm{~kg}$ superphosphate ha ${ }^{-1}$ could be highly recommended to increase the yield of soybean. Soil properties also markedly affected by addition of the elemental S. Soil pH decreased from 7.53 at S0P0 (control) to 7.12 at S3P3 treatment. Available P showed another pattern, its highest values were 44.22 and $45.65 \mathrm{mg} \mathrm{kg}^{-1}$ as results of S2P3 and S3P3 additions and without significant differences between them. The current study confirmed the positive role of the elemental $\mathrm{S}$ in improving both soil fertility and soybean production in the chosen clayey soil under field conditions.
\end{abstract}

Keywords: Soybean, Soil properties, Yield, Elemental S, P fertilization

\section{Introduction}

Soybean (Glycine max L.) is considered as one of the most important and valuable crops in leguminosae (Fabaceae) family and its production is expected to reach 371.3 million tons by 2030 (Masuda \& Goldsmith, 2009 and Kravchenko et al., 2013 ). It is extensively planted in many countries under different environments with a short duration around the world and has high nutritional value, with multiple uses as food and industrial products (Kravchenko et al., 2013 and Yadav et al., 2013). It also contains high amounts of minerals, salts, vitamins (thiamine and riboflavin), protein (an average of 36-43\%) and oil (19-20\%) (Macak \& Candrakova , 2013 and Yadav et al., 2013), and amino acid lysine $(5 \%)$, which is usually deficient in many cereal crops. The presence of isoflavones in soybean can be helpful in preventing infection of human with heart diseases and cancer (Bhattacharjee et al., 2013). Also, there are many other products such as milk and flour can be extracted from it. Growing soybean can maintain the soil fertility through increasing fixation of atmospheric $\mathrm{N}(125-150 \mathrm{~kg}$ $\mathrm{N} \mathrm{ha}^{-1}$ ) and this may reduce nitrogen requirements for plants ( Yadav et al., 2013).

Phosphorus is an essential macro-element and has a vital role in enhancing process of photosynthesis and production of phytin, protein and phospholipids, and in improving both growth and yield of legume crops. Moreover, $\mathrm{P}$ can enhance leaf area, nucleus formation, cell division, carbohydrate metabolism, formation of chlorophyll, nodule numbers and mass of legumes and increase their capacity in the biological fixation of atmospheric N (Rahman et al., 2008 and Yadav et al., 2013). Legumes need a lot of energy and high amounts of $\mathrm{P}$ in the fixation symbiotic process of atmospheric $\mathrm{N}$ (Schulze et al., 2006). Chemical fertilizers such as super-phosphate and rock-phosphate are the main sources of $\mathrm{P}$ but their use efficiency is low in the soil. Moreover, most of the applied P in the soil can be converted to unavailable forms for plants through the precipitation reaction with calcium $\left(\mathrm{Ca}^{2+}\right)$ in both normal and calcareous

*Corresponding author: E-mail: maha.ali@fagr.bu.edu.eg

DOI : 10.21608/ejss.2018.11587

(C)2018 National Information and Documentation Center (NIDOC) 
soils (Gyaneshwar et al., 2002, Turan et al., 2006 and Kravchenko et al., 2013). The needed doses of $\mathrm{P}$ in soil are usually depended on soil fertility, genotype and soil properties, especially $\mathrm{pH}$.

Elemental sulfur (S) is a natural material and can be applied to improve availability of nutrients and decline their deficiencies in calcareous and alkaline soils (Neilsen et al., 1993 and Manesh et al., 2013). Sulphur has a vital role in activation of photosynthesis process, carbohydrate metabolism and certain enzyme systems in plants, and can enhance seed and oil yields, and protein contents (Chatterjee et al., 1992, Abdallah et al., 2010 and Yadav et al., 2013) It is considered as an important nutrient in the synthesis of some benefit compounds such as chlorophyll in soybean leaves and vitamins (biotin and thiamine) and amino acids, including cystine, cysteine and methionine in its seeds. It has positive effects on root growth, the nodulation of legume crops, nitrate reduction and $\mathrm{N}$ assimilation by root nodules (Bhattacharjee et al., 2013). So, its application leads to high increases in the fixed amounts of $\mathrm{N}$ by legumes from the atmosphere and consequently causes marked enhancements in soil fertility (Habtemichial et al., 2007).

The limited presence of $\mathrm{P}$ in soils can be highly responsible for low growth and production of soybean (Sandeep et al., 2008 and Darwesh et al., 2013). The lack of $P$ in the soil has negative effects on nodulation of legumes, so increasing $\mathrm{P}$ availability is considered as an important task to solve this problem (Carsky et al., 2001). Also, the decrease of $\mathrm{P}$ availability and contents can diminish the growth and productivity of legume plants. High precipitation of $\mathrm{P}$ and its low use efficiency in most of Egyptian soils can be resulted from their high $\mathrm{pH}$ values and low microbial activities (Kravchenko et al., 2013, Turan et al., 2006 and Darwesh et al.,2013). So, $P$ in these soils is presented in unavailable and non-suitable forms for plant absorption and this leads to large additions from it to increase the growth and yield of crops. In the presence of the unfavorable conditions, application of P by chemical fertilizers may be not good enough to solve the low availability of $\mathrm{P}$ in soils. Thus, it is very interesting to find a good way to improve $\mathrm{P}$ nutrition and convert it from the insoluble forms to soluble fractions through using some conditioners that can affect and decrease soil $\mathrm{pH}$. It was recorded that addition of $\mathrm{S}$ also can encourage the absorption of micronutrients by plants from high-pH soils through decreasing their $\mathrm{pH}$ values (Manesh et al., 2013). No sufficient information are available about effects of elemental $\mathrm{S}$ and $\mathrm{P}$ fertilization on nutrient, protein and oil contents of soybean that grown on clayey soils under field conditions in Egypt. Recently, there is a great interesting to increase the growing area of soybean as one of the most important industrial crops. In Egypt, the growth area and productivity of soybean is quite low in comparison to other developing and developed countries. So, it is necessary to find a good fertilization strategy through evaluating effects of different levels of $\mathrm{S}$ and $\mathrm{P}$ and their combination on soybean productivity under these conditions. The aims of this investigation are to evaluate the influence of elemental $\mathrm{S}$ on soil $\mathrm{pH}$ and available $\mathrm{P}$, and estimate the best $\mathrm{S}$ and $\mathrm{P}$ application rates in increasing soybean growth and yield.

\section{Materials and Methods}

\section{Seeds and microbial inoculators}

Soybean seeds (variety Giza 83) were obtained from the Oil Crops Research Department, Field Crops Research Institute, Agricultural Research Center (ARC) Giza, Egypt. Okadeen ( $\mathrm{N}$ fixing bacteria) was purchased from the Biofertilizers Production Unit, Agricultural Microbiology Department at the institute of Soils, Water and Environment Research, ARC, Giza, Egypt.

\section{Field experiment}

A field experiment was conducted in 1 May 2013 at the Research Farm of Faculty of Agriculture, Benha University, Egypt. The experiment was factorial with two factors ( $S$ levels and P levels) and designed as a randomized complete block design. Sixteen treatments with three replicates were performed in the experiment resulted from the combination of four rates of $\mathrm{S}\left(\mathrm{S} 1=0, \mathrm{~S} 1=119, \mathrm{~S} 2=238\right.$ and $\left.\mathrm{S} 3=357 \mathrm{~kg} \mathrm{ha}^{-1}\right)$ and four rates of $\mathrm{P}(\mathrm{P} 0=0, \mathrm{P} 1=238, \mathrm{P} 2=476$ and P3 $=714 \mathrm{~kg}$ superphosphate ha $\left.{ }^{-1}\right)$. So, 48 field plots were set up and the size of each plot was $5 \mathrm{~m}^{2}(2.5$ $\mathrm{m}$ length $\mathrm{x} 2 \mathrm{~m}$ width). Each plot was contained 4 rows and the distance between the rows was $50 \mathrm{~cm}$. The used sources of S and P were elemental S (98\% S) and superphosphate $\left(15.5 \% \mathrm{P}_{2} \mathrm{O}_{5}\right)$, respectively. The recommended dose of $\mathrm{P}$ for soybean was 476 superphosphate/ha. The desired plant density for soybean was $83.3 \mathrm{~kg}$ seeds ha- ${ }^{-1}$. Elemental S was added during preparation of the field (one month before sowing of soybean), while superphosphate was used one week before sowing of soybean. Seeds of soybean were mixed thoroughly with Okadeen one hour prior to their sowing in the soil at a rate of $952 \mathrm{~g}$ inoculum/ha. The Arabic gum

Egypt. J. Soil Sci., 58, No. 2 (2018) 
solution (16\%) was used as an adhesive agent to fix the inoculum with soybean seeds (Badawi et al., 2011). After that, 5 seeds of soybean were sown in a small whole and the distance between the wholes was $15 \mathrm{~cm}$. Soybean plants were thinned to 3 plants after their full germination. Urea and potassium sulfate were applied at doses of $102 \mathrm{~kg}$ $\mathrm{ha}^{-1}$ (47.4 $\mathrm{kg} \mathrm{N} \mathrm{ha}^{-1}$ ) and $119 \mathrm{~kg} \mathrm{ha}^{-1}$, respectively. The applied $\mathrm{N}$ was used as an activation dose for soybean and added after plants thinning. Potassium fertilizer was added before the second irrigation. The experimental plots were irrigated every 10 days and the irrigation was stopped 3 weeks before the harvest process.

\section{Soil analyses}

Soil $\mathrm{pH}$ was determined in a suspension of 1:2.5 (soil: water), while soil electrical conductivity (EC) was measured in soil paste extract. The particle size distribution was determined by the pipette method (Sheldrick and Wang., 1993). Soil organic matter was measured as described by page etal (1982). Total amounts of $\mathrm{N}, \mathrm{P}$ and $\mathrm{K}$ in the soil were determined after its digestion with a strong mixture of $\mathrm{H}_{2} \mathrm{SO}_{4}$ and $\mathrm{HClO}_{4}(2: 1, \mathrm{v}: \mathrm{v})$ according to A.O.A.C. (1995). Available soil phosphorus was evaluated by the spectrophotometer after its extraction by sodium bicarbonate (Olsen and Dommers, 1982). Soil available $\mathrm{N}$ and $\mathrm{K}$ were measured according to the standard methods as mentioned by (Rowel, 1994). Carbonate El-Calcium was determined by using calcimeter according to Balazs et al. (2005). The main chemical and physical properties of the soil are presented in Table 1.

TABLE 1. Some physical and chemical properties of the soil sample

\begin{tabular}{lc}
\hline Properties & Values \\
\hline $\mathrm{EC}\left(\mathrm{dS} \mathrm{m}{ }^{-1}\right.$ in soil paste $)$ & 1.43 \\
$\mathrm{pH}($ in $1: 2.5$ suspension $)$ & 7.56 \\
Total organic matter $\left(\mathrm{g} \mathrm{kg}^{-1}\right)$ & 18.75 \\
Total $\mathrm{N}\left(\mathrm{g} \mathrm{kg}^{-1}\right)$ & 2.12 \\
Total P $\left(\mathrm{g} \mathrm{kg}^{-1}\right)$ & 1.03 \\
Total $\mathrm{K}\left(\mathrm{g} \mathrm{kg}^{-1}\right)$ & 9.51 \\
Available N $\left(\mathrm{mg} \mathrm{kg}^{-1}\right)$ & 41.05 \\
Available P $\left(\mathrm{mg} \mathrm{kg}^{-1}\right)$ & 22.63 \\
Available K $\left(\mathrm{mg} \mathrm{kg}^{-1}\right)$ & 160.73 \\
CaCO $\left(\mathrm{g} \mathrm{kg}^{-1}\right)$ & 13.28 \\
Sand $(\%)$ & 8.39 \\
Silt $(\%)$ & 15.41 \\
Clay $(\%)$ & 76.20 \\
Soil texture & Clay \\
\hline
\end{tabular}

\section{Plant analyses}

Soybean plants were harvest at the physiological maturity stage in mid of August and they divided into two parts (shoots and pods). All pods were separated and accounted to determine their numbers. Samples of soybean shoots and seeds were oven-dried at $60-70{ }^{\circ} \mathrm{C}$ for $48 \mathrm{~h}$ and their dry weights were recorded. The pods were manually crushed and the seeds were collected and balanced to determine the yield. Sub-samples of the oven-dried seeds were digested as describe for soil samples. Total nitrogen contents in soybean seeds were determined according to Kjeldahl digestion and distillation method (Lepo and Ferrenbach., 1990). To estimate the crude protein, the percent of $\mathrm{N}$ in soybean seeds was multiplied by 6.25 . Oil contents in soybean seeds were determined by Soxhlet method (Sadasivam and Manickam ., 1996). Briefly, seeds of soybean were crushed to powder using an electrical mill. A sample of $2 \mathrm{~g}$ was placed into the apparatus flask and the oil was extracted by petroleum ether for 8 $\mathrm{h}$. The used flask was transferred to an oven for 2 $\mathrm{h}$ at $80^{\circ} \mathrm{C}$ to remove the excess solvent and then cooled to determine the oil weight. Phosphorus and potassium concentrations were determined by spectrophotometer and flame photometer, respectively as describe by (Kaya et al., 2009).

\section{Statistical analysis}

Data were subjected to the statistical analysis using software of SPSS (version 16.0). The least significant difference (LSD) was performed at 5\% probability to evaluate the significant differences among the experimental treatments according to Snedecor and Cochran (1991).

\section{$\underline{\text { Results }}$}

\section{Branch and pod numbers}

Data in Table 2 showed that branch and pod numbers of soybean were markedly increased due to response to $\mathrm{S}$ and $\mathrm{P}$ applications. In general, the increase of $\mathrm{S}$ and $\mathrm{P}$ applied rates had a significant effect on numbers of soybean branch and pod. Under no $\mathrm{S}$ and $\mathrm{P}$ addition (control= S0P0), the branch and pod numbers were 2.49 and 25.72 respectively, and then increased to 3.60 and 33.53 after addition of P3. At S1, numbers of soybean branch and pod increased from 2.65 and 27.58 at P0 to 4.15 and 37.08 at high dose of phosphorus $\mathrm{P} 3$, while increasing $\mathrm{S}$ dose to $\mathrm{S} 2$, branch and pod raised from 3.01 and 30.64 at P0 to 4.65 and 41.24 at P3. Applying S3 level was responsible for the highest increases in branch and pod numbers (4.73 and 42.00) at P3. No significant 
difference changes were found in branch and pod number between S2 and S3 at all applied $\mathrm{P}$ rates. This indicated that $\mathrm{S} 2$ could be used as good and suitable dose to increase branch and pod number of soybean plants. Among P applied levels, P3 led to the highest increases in branch and pod numbers at all applied S rates. However, there were no significant increases recorded in branch and pod numbers between P2 and P3 at all used $\mathrm{S}$ rates. Therefore, this result could be used to indicate that P2 had the same effect of P3 on branch and pod number.

\section{Seeds and straw yield}

Application of $\mathrm{S}$ and $\mathrm{P}$ at different doses was generally increased seeds and straw yields of soybean and increasing the applied rates led to observable enhancements in yields (Table 3). Improvements were observed in soybean seeds and straw from $2.15,2.75 \mathrm{tha}^{-1}$ at $\mathrm{S} 0$ to $2.23,2.93$,
2.34, 3.19 and 2.42, $3.30 \mathrm{t} \mathrm{ha}^{-1}$ due to additions of S1, S2 and S3, respectively in the absence of phosphorus addition P0. At P3 level these values were raised up to $3.25-4.03,3.71-4.38,4.00$ 4.96 and 4.12-5.01 as results of S0, S1, S2 and $\mathrm{S} 3$ applications, respectively. The maximum seed and straw yields (4.00-4.96 $\mathrm{t} \mathrm{ha}^{-1}$ and 4.12-5.01 $\left.\mathrm{t} \mathrm{ha}^{-1}\right)$ were recorded in the presence of P3 rate at S2 and S3, respectively. Marked increases in seeds and straw yields recorded when the dose of $\mathrm{P}$ increased from P1 to P2. However, increase of $\mathrm{P}$ rates from $\mathrm{P} 2$ to $\mathrm{P} 3$ had no significant effects on seeds and straw yields at all $\mathrm{S}$ rates. No significant effects on seeds and straw yields of soybean were found between $\mathrm{S} 2$ and $\mathrm{S} 3$ at the experimental rates of $\mathrm{P}$ and also between $\mathrm{P} 2$ and $\mathrm{P} 3$ at all levels of S. So, it is interesting to mention that using P3 and S3 had same influence of S2 and P2 on seeds and straw yields of soybean.

TABLE 2. Branch and pod numbers of soybean as affected by $S$ and $P$ fertilizers

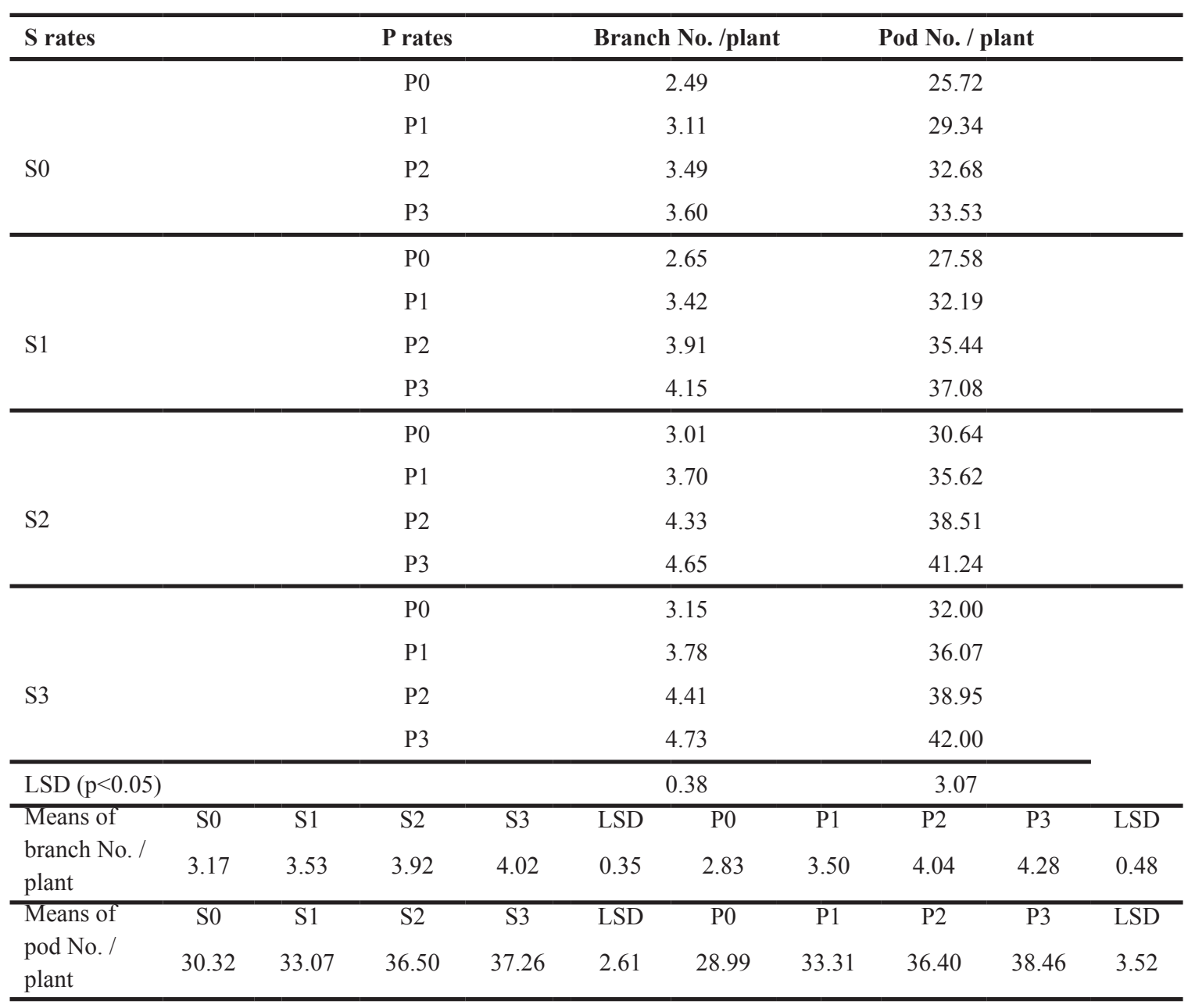

$\mathrm{S} 0=$ zero, $\mathrm{S} 1=119, \mathrm{~S} 2=238$ and $\mathrm{S} 3=357 \mathrm{~kg} \mathrm{ha}^{-1} . \mathrm{P} 1=238, \mathrm{P} 2=476$ and $\mathrm{P} 3=714 \mathrm{~kg}$ superphosphate $\mathrm{ha}^{-1}$. 
TABLE 3. Seeds and straw yields of soybean as affected by $S$ and $P$ fertilizers

\begin{tabular}{|c|c|c|c|c|c|c|c|c|c|c|}
\hline \multirow[t]{2}{*}{$S$ rates } & \multicolumn{4}{|c|}{$P$ rates } & \multicolumn{2}{|c|}{$\begin{array}{l}\text { Seed yield } \\
\left(\mathrm{t} \mathrm{ha}^{-1}\right)\end{array}$} & \multicolumn{2}{|c|}{$\begin{array}{l}\text { Straw yield } \\
\left(\mathrm{t} \mathrm{ha}^{-1}\right)\end{array}$} & & \\
\hline & & & $\mathrm{P} 0$ & & & 2.15 & & 2.75 & & \\
\hline \multirow{3}{*}{ So } & & & $\mathrm{P} 1$ & & & 2.83 & & 3.46 & & \\
\hline & & & $\mathrm{P} 2$ & & & 3.17 & & 3.91 & & \\
\hline & & & P3 & & & 3.25 & & 4.03 & & \\
\hline \multirow{4}{*}{ S1 } & & & $\mathrm{P} 0$ & & & 2.23 & & 2.93 & & \\
\hline & & & $\mathrm{P} 1$ & & & 2.95 & & 3.61 & & \\
\hline & & & $\mathrm{P} 2$ & & & 3.50 & & 4.10 & & \\
\hline & & & $\mathrm{P} 3$ & & & 3.71 & & 4.38 & & \\
\hline \multirow{4}{*}{ S2 } & & & P0 & & & 2.34 & & 3.19 & & \\
\hline & & & $\mathrm{P} 1$ & & & 3.20 & & 4.01 & & \\
\hline & & & $\mathrm{P} 2$ & & & 3.85 & & 4.64 & & \\
\hline & & & P3 & & & 4.00 & & 4.96 & & \\
\hline \multirow{4}{*}{ S3 } & & & $\mathrm{P} 0$ & & & 2.42 & & 3.30 & & \\
\hline & & & $\mathrm{P} 1$ & & & 3.26 & & 4.10 & & \\
\hline & & & P2 & & & 3.84 & & 4.73 & & \\
\hline & & & P3 & & & 4.12 & & 5.01 & & \\
\hline $\operatorname{LSD}(\mathrm{p}<0.05)$ & & & & & & 0.30 & & 0.42 & & \\
\hline \multirow{2}{*}{$\begin{array}{l}\text { Means of } \\
\text { seed yield }\end{array}$} & S0 & $\mathrm{S} 1$ & $\mathrm{~S} 2$ & $\mathrm{~S} 3$ & LSD & $\mathrm{P} 0$ & $\mathrm{P} 1$ & $\mathrm{P} 2$ & P3 & LSD \\
\hline & 2.85 & 3.10 & 3.35 & 3.41 & 0.24 & 2.29 & 3.06 & 3.59 & 3.77 & 0.38 \\
\hline \multirow{2}{*}{$\begin{array}{l}\text { Means of } \\
\text { straw yield }\end{array}$} & S0 & $\mathrm{S} 1$ & $\mathrm{~S} 2$ & S3 & LSD & $\mathrm{P} 0$ & $\mathrm{P} 1$ & $\mathrm{P} 2$ & P3 & \\
\hline & 3.54 & 3.76 & 4.20 & 4.29 & 0.21 & 3.04 & 3.80 & 4.35 & 4.60 & 0.33 \\
\hline
\end{tabular}

$\mathrm{S} 0=$ zero, $\mathrm{S} 1=119, \mathrm{~S} 2=238$ and $\mathrm{S} 3=357 \mathrm{~kg} / \mathrm{ha} . \mathrm{P} 1=238, \mathrm{P} 2=476$ and $\mathrm{P} 3=714 \mathrm{~kg}$ superphosphate $/ \mathrm{ha}$.

\section{Nodules and plant height}

Effects of $\mathrm{S}$ and $\mathrm{P}$ at different applied rates on soybean height and nodules number on the roots are presented in Table 4 . Soybean height and its root nodules significantly enhanced with increasing $\mathrm{S}$ and $\mathrm{P}$ rates and the increases were more noticeable at P2 and P3 as compared with $\mathrm{P} 0$. Addition of $\mathrm{P} 3$ caused the same effects on height and nodules number of soybean as P2 under all levels of S. At S0, numbers of nodules were 63.08, 70.29, 78.34 and 82.11 at P0, P1, P2 and $\mathrm{P} 3$, respectively, which they reached to highest values of $(70.84,86.94,103.46$ and 109.08) when the soil treated with $\mathrm{S} 3$. Using S3 in comparison to $\mathrm{S} 2$ did not lead to significant increases in nodules number on soybean roots. So, application of S3 should be not recommended as an economical dose for soybean.
The largest values of soybean height (59.26, $67.26,74.18$ and $77.55 \mathrm{~cm}$ ) were noticed under S3, whereas the lowest ones $(52.61,57.71$, 62.20 and $63.09 \mathrm{~cm}$ ) were found under S0 when P0, P1, P2 and P3 were applied, respectively. Increasing applied $\mathrm{S}$ rates from $\mathrm{S} 0$ to $\mathrm{S} 1$ had no marked effect on soybean height only at P1 and $\mathrm{P} 2$ but at P3 there was a significant difference. Moreover, increasing S level from S2 to S3 did not affect the height of soybean under all doses of P. No notable enhancements were found in soybean height due to using P2 or P3 under all applied rates of $\mathrm{S}$. So, the addition of $\mathrm{S} 2$ and P2 could be suggested as good rates in the fertilization of soybean to increase its height and root nodules. 
TABLE 4. Plant height (at the harvest) and nodulation (at 60 days) of soybean as affected by $S$ and $P$ fertilizers

\begin{tabular}{|c|c|c|c|c|c|c|c|c|c|c|}
\hline \multirow[t]{2}{*}{$S$ rates } & & \multicolumn{3}{|c|}{$P$ rates } & \multicolumn{2}{|c|}{ Nodule No. / plant } & \multicolumn{3}{|c|}{ Plant height (cm) } & \\
\hline & & & P0 & & \multicolumn{2}{|c|}{63.08} & \multicolumn{3}{|c|}{52.61} & \\
\hline \multirow{3}{*}{ S0 } & & & $\mathrm{P} 1$ & & \multicolumn{2}{|c|}{70.29} & \multicolumn{3}{|c|}{57.71} & \\
\hline & & & $\mathrm{P} 2$ & & \multicolumn{2}{|c|}{78.34} & \multicolumn{3}{|c|}{62.20} & \\
\hline & & & P3 & & \multicolumn{2}{|c|}{82.11} & \multicolumn{3}{|c|}{63.09} & \\
\hline \multirow{4}{*}{ S1 } & & & $\mathrm{P} 0$ & & \multicolumn{2}{|c|}{69.11} & \multicolumn{3}{|c|}{54.03} & \\
\hline & & & P1 & & \multicolumn{2}{|c|}{77.21} & \multicolumn{3}{|c|}{60.24} & \\
\hline & & & $\mathrm{P} 2$ & & \multicolumn{2}{|c|}{90.36} & \multicolumn{3}{|c|}{65.82} & \\
\hline & & & P3 & & \multicolumn{2}{|c|}{95.53} & \multicolumn{3}{|c|}{68.15} & \\
\hline \multirow{4}{*}{$\mathrm{S} 2$} & & & $\mathrm{P} 0$ & & \multicolumn{2}{|c|}{75.29} & \multicolumn{3}{|c|}{57.14} & \\
\hline & & & $\mathrm{P} 1$ & & \multicolumn{2}{|c|}{84.67} & \multicolumn{3}{|c|}{65.28} & \\
\hline & & & P2 & & \multicolumn{2}{|c|}{98.79} & \multicolumn{3}{|c|}{71.43} & \\
\hline & & & P3 & & \multicolumn{2}{|c|}{104.3} & \multicolumn{3}{|c|}{74.00} & \\
\hline & & & $\mathrm{P} 0$ & & \multicolumn{2}{|c|}{70.84} & \multicolumn{3}{|c|}{59.26} & \\
\hline & & & $\mathrm{P} 1$ & & & 6.94 & & 67.2 & & \\
\hline S3 & & & $\mathrm{P} 2$ & & & 03.46 & & 74.1 & & \\
\hline & & & $\mathrm{P} 3$ & & & 09.08 & & 77.5 & & \\
\hline $\operatorname{LSD}(\mathrm{p}<0.05)$ & & & & & 5.60 & & 3.6 & & & \\
\hline Means of & S0 & $\mathrm{S} 1$ & $\mathrm{~S} 2$ & $\mathrm{~S} 3$ & LSD & $\mathrm{P} 0$ & $\mathrm{P} 1$ & $\mathrm{P} 2$ & $\mathrm{P} 3$ & LSD \\
\hline $\begin{array}{l}\text { nodule No. / } \\
\text { plant }\end{array}$ & 73.46 & 83.05 & 90.76 & 92.58 & 4.63 & 69.58 & 79.78 & 92.74 & 97.76 & 4.92 \\
\hline Means of Plant & S0 & S1 & S2 & S3 & LSD & $\mathrm{P} 0$ & $\mathrm{P} 1$ & $\mathrm{P} 2$ & P3 & LSD \\
\hline height & 58.90 & 62.06 & 66.96 & 69.56 & 3.45 & 55.76 & 62.62 & 68.41 & 70.70 & 3.71 \\
\hline
\end{tabular}

$\mathrm{S} 0=$ zero, $\mathrm{S} 1=119, \mathrm{~S} 2=238$ and $\mathrm{S} 3=357 \mathrm{~kg} \mathrm{ha}^{-1} . \mathrm{P} 1=238, \mathrm{P} 2=476$ and $\mathrm{P} 3=714 \mathrm{~kg}$ superphosphate $\mathrm{ha}^{-1}$.

\section{Nutrient contents}

Concentrations of $\mathrm{N}, \mathrm{P}$ and $\mathrm{K}$ in soybean seeds were significantly affected by the applications of $\mathrm{S}$ and $\mathrm{P}$ fertilizers (Table 5). Generally, the increase of applied S and P rates led to high improvements in $\mathrm{N}$ concentrations in soybean seed. However, at S0, there were no significant increases in $\mathrm{N}$ concentrations at $\mathrm{P} 2$ and $\mathrm{P} 3$. At other $\mathrm{S}$ rates (S1, S2 and S3), the increase of P level from P2 to P3 caused significant increases in $\mathrm{N}$ concentrations. However, increase of S rate from S2 to S3 had no significant effect on $\mathrm{N}$ values at P1, P2 and $\mathrm{P} 3$. The highest $\mathrm{N}$ concentrations (5.53, $5.75,6.01$ and $6.49 \%$ ) were resulted when $\mathrm{S}$ was applied at a rate of S3 under using $\mathrm{P} 0$, $\mathrm{P} 1, \mathrm{P} 2$ and $\mathrm{P} 3$, respectively. In contrast, the lowest $\mathrm{N}$ concentrations $(5.17,5.40,5.65$ and $5.78 \%$ ) were obtained with P0, P1, P2 and P3, respectively at $\mathrm{S} 0$.
Increasing P level from P1 to P2 and P3 had significant effect on $\mathrm{P}$ concentrations in soybean seeds at all applied $\mathrm{S}$ doses and the effect of P3 was higher than that of P1 and P2. Addition of S3 had more noticeable effect on P concentrations as compared to other rates ( $\mathrm{S} 0, \mathrm{~S} 1$ and $\mathrm{S} 2)$ at all used $\mathrm{P}$ levels. The lowest $\mathrm{P}$ concentrations were 0.16 , $0.23,0.29$ and $0.37 \%$ at $\mathrm{S} 0$, whereas the highest concentrations were $0.35,0.42,0.60$ and $0.78 \%$ at $\mathrm{S} 3$ after application of $\mathrm{P} 1, \mathrm{P} 2$ and $\mathrm{P} 3$, respectively.

Potassium concentrations in soybean seeds did not show marked response for $\mathrm{P}$ application at $\mathrm{S} 0$ but the increase of $\mathrm{P}$ levels had significant effect on $\mathrm{K}$ concentrations at other $\mathrm{S}$ levels (S1, $\mathrm{S} 2$ and S3). The use of S3 was responsible for the maximum concentrations of $\mathrm{K}(2.70,2.91$, 3.22 and $3.46 \%$ ) but S0 led to the lowest values $(2.49,2.58,2.66$ and $2.73 \%)$ at $\mathrm{P} 0, \mathrm{P} 1, \mathrm{P} 2$ and $\mathrm{P} 3$, respectively. 
TABLE 5. Nutrient concentrations $(\%)$ of soybean as affected by $S$ and $P$ fertilizers

\begin{tabular}{|c|c|c|c|c|c|c|c|c|c|c|}
\hline \multirow[t]{2}{*}{$S$ rates } & \multicolumn{3}{|c|}{$P$ rates } & \multicolumn{2}{|r|}{$\% \mathrm{~N}$} & \multicolumn{2}{|r|}{$\% \mathrm{P}$} & \multicolumn{2}{|r|}{$\% \mathrm{~K}$} & \\
\hline & \multicolumn{3}{|c|}{ P0 } & \multicolumn{2}{|r|}{5.17} & \multicolumn{2}{|r|}{0.16} & \multicolumn{2}{|r|}{2.49} & \\
\hline \multirow{3}{*}{ S0 } & \multicolumn{3}{|c|}{$\mathrm{P} 1$} & \multicolumn{2}{|r|}{5.40} & \multicolumn{2}{|r|}{0.23} & \multicolumn{2}{|r|}{2.58} & \\
\hline & \multicolumn{3}{|c|}{$\mathrm{P} 2$} & \multicolumn{2}{|r|}{5.65} & \multicolumn{2}{|r|}{0.29} & \multicolumn{2}{|r|}{2.66} & \\
\hline & \multicolumn{3}{|c|}{ P3 } & \multicolumn{2}{|r|}{5.78} & \multicolumn{2}{|r|}{0.37} & \multicolumn{2}{|r|}{2.73} & \\
\hline \multirow{4}{*}{$\mathrm{S} 1$} & \multicolumn{3}{|c|}{ P0 } & \multicolumn{2}{|r|}{5.30} & \multicolumn{2}{|r|}{0.23} & \multicolumn{2}{|r|}{2.57} & \\
\hline & \multicolumn{3}{|c|}{$\mathrm{P} 1$} & \multicolumn{2}{|r|}{5.53} & \multicolumn{2}{|r|}{0.28} & \multicolumn{2}{|r|}{2.65} & \\
\hline & \multicolumn{3}{|c|}{$\mathrm{P} 2$} & & 5.81 & & 0.40 & & 2.84 & \\
\hline & & P3 & & & 6.20 & & 0.50 & & 3.06 & \\
\hline & & P0 & & & 5.45 & & 0.29 & & 2.63 & \\
\hline & & $\mathrm{P} 1$ & & & 5.68 & & 0.35 & & 2.73 & \\
\hline S2 & & $\mathrm{P} 2$ & & & 5.97 & & 0.51 & & 2.98 & \\
\hline & & P3 & & & 6.35 & & 0.65 & & 3.24 & \\
\hline & & P0 & & & 5.53 & & 0.35 & & 2.70 & \\
\hline & & P1 & & & 5.75 & & 0.42 & & 2.91 & \\
\hline S3 & & $\mathrm{P} 2$ & & & 6.01 & & 0.60 & & 3.22 & \\
\hline & & $\mathrm{P} 3$ & & & 6.49 & & 0.78 & & 3.46 & \\
\hline $\operatorname{LSD}(\mathrm{p}<0.05)$ & & & & & 0.20 & & 0.05 & & 0.15 & \\
\hline Means of $\mathrm{N} \%$ & S0 & $\mathrm{S} 1$ & $\mathrm{~S} 2$ & S3 & LSD & $\mathrm{P} 0$ & $\mathrm{P} 1$ & $\mathrm{P} 2$ & P3 & LSD \\
\hline 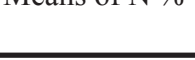 & 5.50 & 5.71 & 5.86 & 5.95 & 0.13 & 5.36 & 5.59 & 5.86 & 6.21 & 0.18 \\
\hline Means of $\mathrm{P} \%$ & S0 & $\mathrm{S} 1$ & $\mathrm{~S} 2$ & $\mathrm{~S} 3$ & LSD & $\mathrm{P} 0$ & $\mathrm{P} 1$ & $\mathrm{P} 2$ & P3 & LSD \\
\hline 198 & 0.26 & 0.35 & 0.45 & 0.54 & 0.04 & 0.26 & 0.32 & 0.45 & 0.58 & 0.04 \\
\hline Means of $\mathrm{K} \%$ & S0 & $\mathrm{S} 1$ & $\mathrm{~S} 2$ & $\mathrm{~S} 3$ & LSD & P0 & $\mathrm{P} 1$ & $\mathrm{P} 2$ & $\mathrm{P} 3$ & LSD \\
\hline & 2.62 & 2.78 & 2.90 & 3.07 & 0.12 & 2.60 & 2.72 & 2.93 & 3.12 & 0.14 \\
\hline
\end{tabular}

$\mathrm{S} 0=$ zero, $\mathrm{S} 1=119, \mathrm{~S} 2=238$ and $\mathrm{S} 3=357 \mathrm{~kg} \mathrm{ha}^{-1} . \mathrm{P} 1=238, \mathrm{P} 2=476$ and $\mathrm{P} 3=714 \mathrm{~kg}$ superphosphate ha ${ }^{-1}$.

Protein and oil contents of soybean seeds

Protein and oil contents were improved with application of $\mathrm{S}$ and $\mathrm{P}$ fertilizers and these effects were generally more noticeable due to the increase of their applied rates (Figs. 1 and 2). There were no significant differences recorded between $\mathrm{P} 2$ and $\mathrm{P} 3$ on oil concentrations in soybean seeds at all used $\mathrm{S}$ rates, and also between $\mathrm{S} 2$ and $\mathrm{S} 3$ at all applied $\mathrm{P}$ rates. Oil contents ranged from $12.31-15.77 \%$ at $\mathrm{S} 0$ to $15.18-17.56 \%, 16.45-$ $19.40 \%$ and $16.84-19.98 \%$ at S1, S2 and S3, respectively. Addition of $\mathrm{S} 2$ had same effect of $\mathrm{S} 3$ and they were responsible for the highest oil contents $(14.29,16.45,18.59$ and $19.40 \%)$ and
$(15.01,16.84,18.76$ and $19.98 \%)$ at P0, P1, P2 and $\mathrm{P} 3$, respectively.

In S0 treatment, differences between protein contents at P2 and P3 were not significant but these changes were significant under other $\mathrm{S}$ rates (S1, S2 and S3). Furthermore, addition of $\mathrm{S} 2$ had same influence as S3 on protein contents at all rates of applied P. Using S1 and S2 at P3 did not caused marked changes in protein contents. It was noticed that S3 produced the highest concentration of protein in soybean seeds (34.56, $35.94,37.65$ and $40.56 \%$ ), whereas S0 led to the lowest contents $(32.31,33.75,35.31$ and $36.13 \%$ ) at $\mathrm{P} 0, \mathrm{P} 1, \mathrm{P} 2$ and $\mathrm{P} 3$, respectively. 


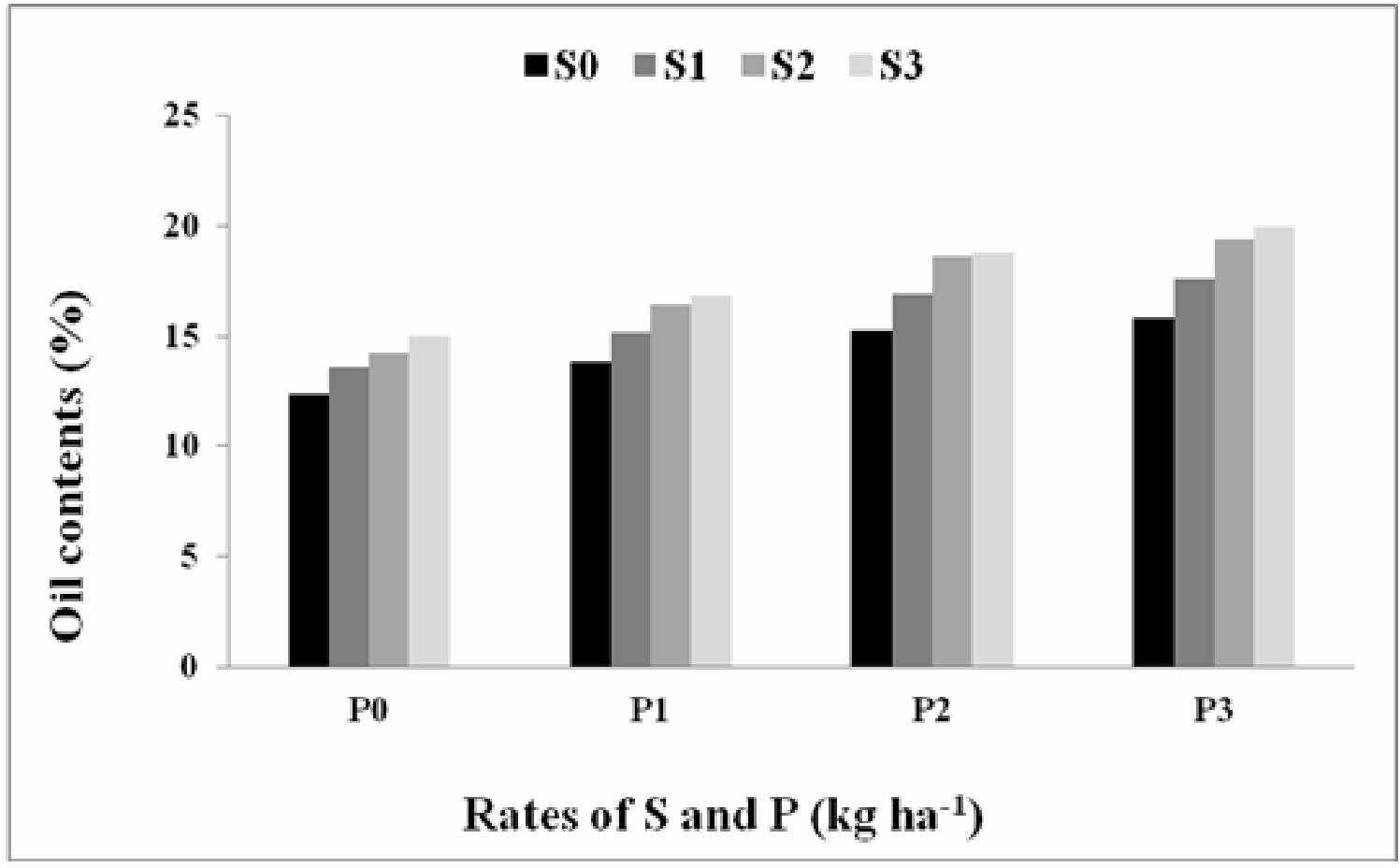

$\mathrm{S} 0=$ zero, $\mathrm{S} 1=119, \mathrm{~S} 2=238$ and $\mathrm{S} 3=357 \mathrm{~kg}$ ha- $1 . \mathrm{P} 1=238, \mathrm{P} 2=476$ and $\mathrm{P} 3=714 \mathrm{~kg}$ superphosphate ha- 1 . LSD for oil content $=1.32$.

Fig. 1. Oil contents in soybean seeds as affected by $S$ and $P$ fertilizers

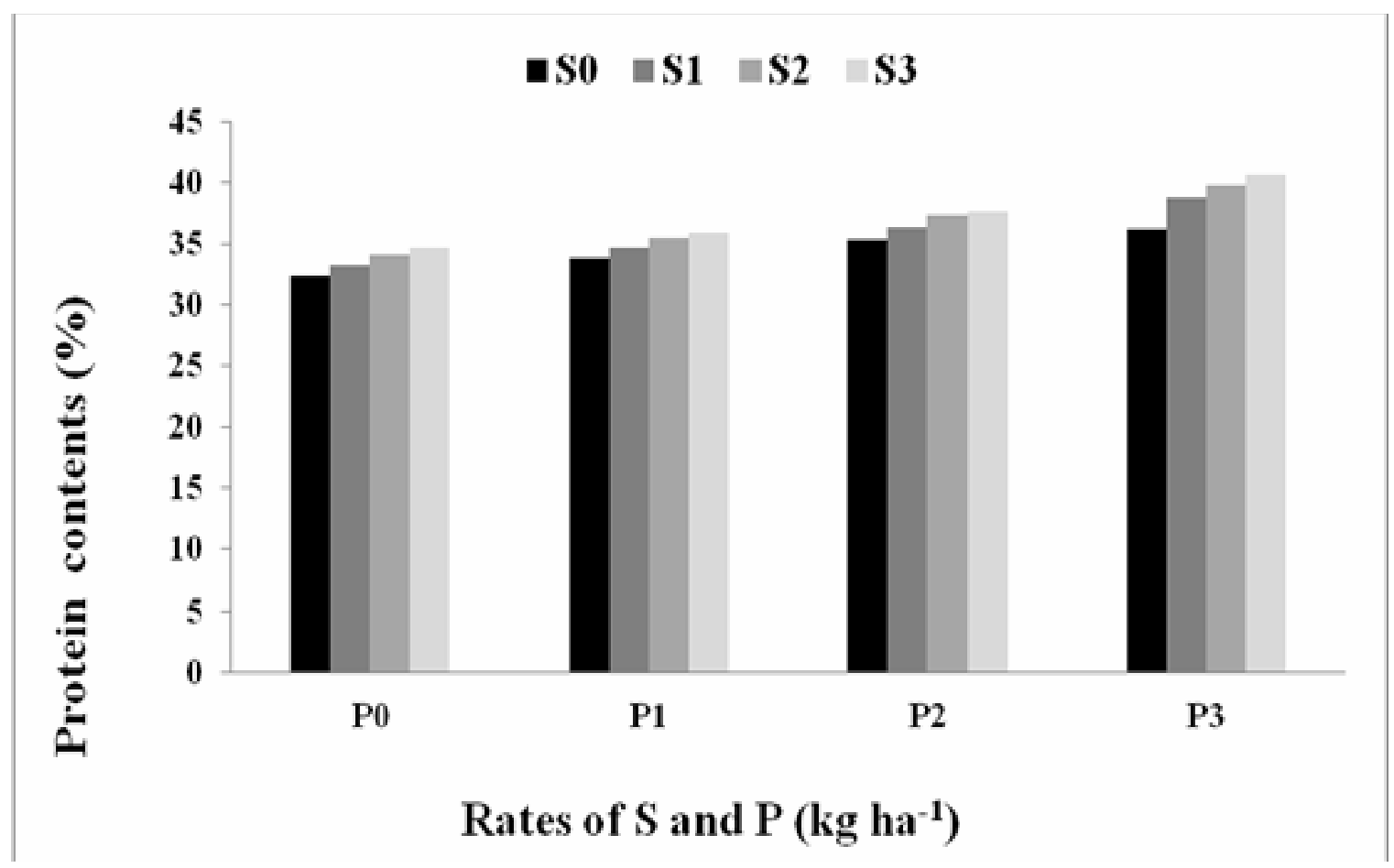

$\mathrm{S} 0=$ zero, $\mathrm{S} 1=119, \mathrm{~S} 2=238$ and $\mathrm{S} 3=357 \mathrm{~kg}$ ha- $1 . \mathrm{P} 1=238, \mathrm{P} 2=476$ and $\mathrm{P} 3=714 \mathrm{~kg}$ superphosphate ha- 1 . LSD for protein content $=1.56$.

Fig. 2. Protein contents in soybean seeds as affected by $S$ and $P$ fertilizers

Egypt. J. Soil Sci., 58, No. 2 (2018) 
Soil $\mathrm{pH}$ and available $P$ as affected by elemental $S$ and $P$ fertilization

Values of soil pH did not influence by application of $\mathrm{P}$ in the soil, whereas the increase of $\mathrm{S}$ rates from S0 to S1, S2 and S3 significantly decreased $\mathrm{pH}$ (Fig.3). Soil $\mathrm{pH}$ declined from 7.53 at $\mathrm{S} 0$ to 7.44, 7.22 and 7.21 at S1, S2 and S3, respectively at $\mathrm{P} 0$. Moreover, $\mathrm{pH}$ values at $\mathrm{P} 3$ decreased from 7.46 to $7.34,7.15$ and 7.12 due to the increase of $\mathrm{S}$ rates from $\mathrm{S} 0$ to $\mathrm{S} 1, \mathrm{~S} 2$ and $\mathrm{S} 3$, respectively. The lowest values of soil $\mathrm{pH}(7.21,7.18,7.15$ and 7.12) were achieved after application of $\mathrm{S} 3$ at $\mathrm{P} 0$, P1, P3 and P3, respectively.
Values of available P significantly increased with increasing applied rates of S and P (Fig.4). The highest values of soil available $\mathrm{P}$ were observed when elemental $\mathrm{S}$ was applied at rates of S2 and S3 and there were no significant differences between them. The lowest rate of $\mathrm{P}$ (P0) did not cause significant increases in available $\mathrm{P}$ values at all applied rates of $\mathrm{S}$. Soil available $\mathrm{P}$ enhanced from $19.34-30.73 \mathrm{mg} \mathrm{kg}^{-1}$ at S0 to $24.15-38.26 \mathrm{mg} \mathrm{kg}^{-1}, 27.83-44.22 \mathrm{mg}$ $\mathrm{kg}^{-1}$ and $29.07-45.65 \mathrm{mg} \mathrm{kg}^{-1}$ at S1, S2 and S3, respectively.

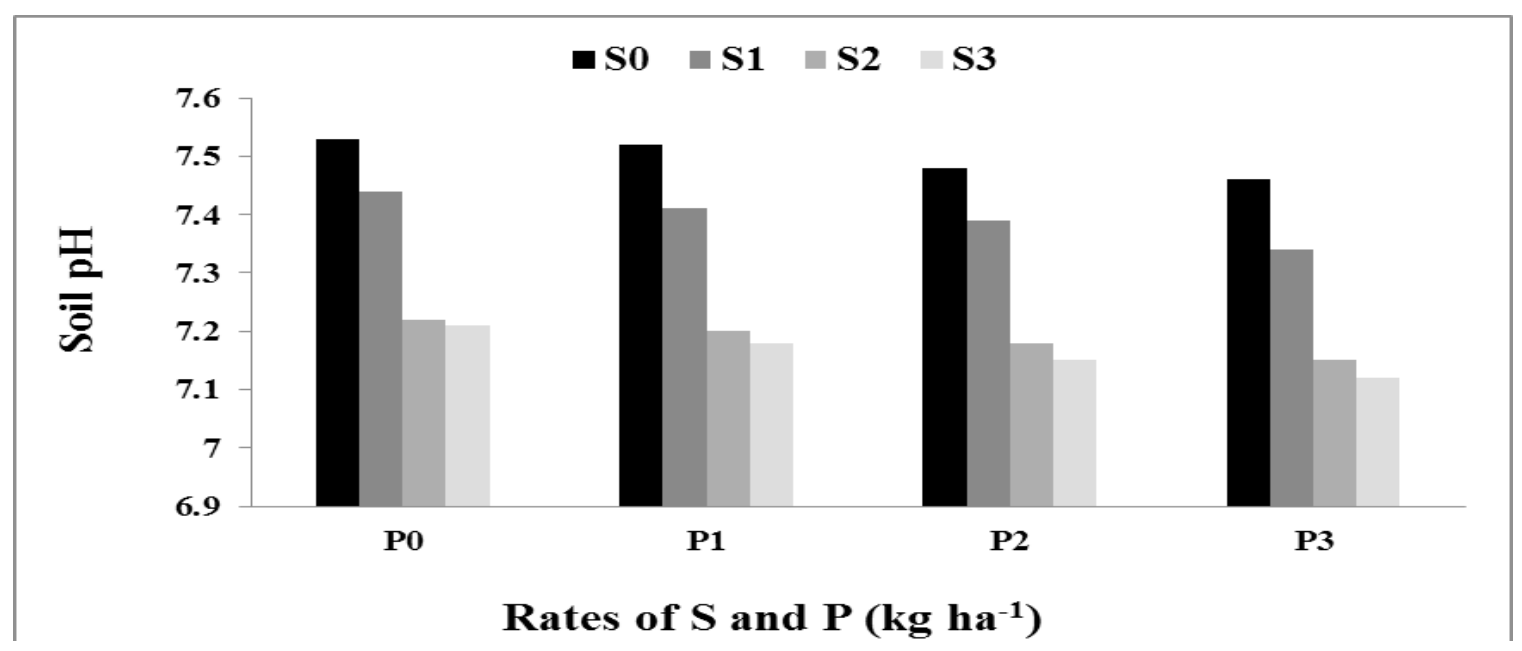

$\mathrm{S} 0=$ zero, $\mathrm{S} 1=119, \mathrm{~S} 2=238$ and $\mathrm{S} 3=357 \mathrm{~kg} \mathrm{ha}^{-1} . \mathrm{P} 1=238, \mathrm{P} 2=476$ and $\mathrm{P} 3=714 \mathrm{~kg}$ superphosphate $\mathrm{ha}^{-1}$. LSD for $\mathrm{pH}$ values $=0.10$

Fig. 3. Soil pH as affected by $S$ and $P$ fertilizers after harvesting soybean plants

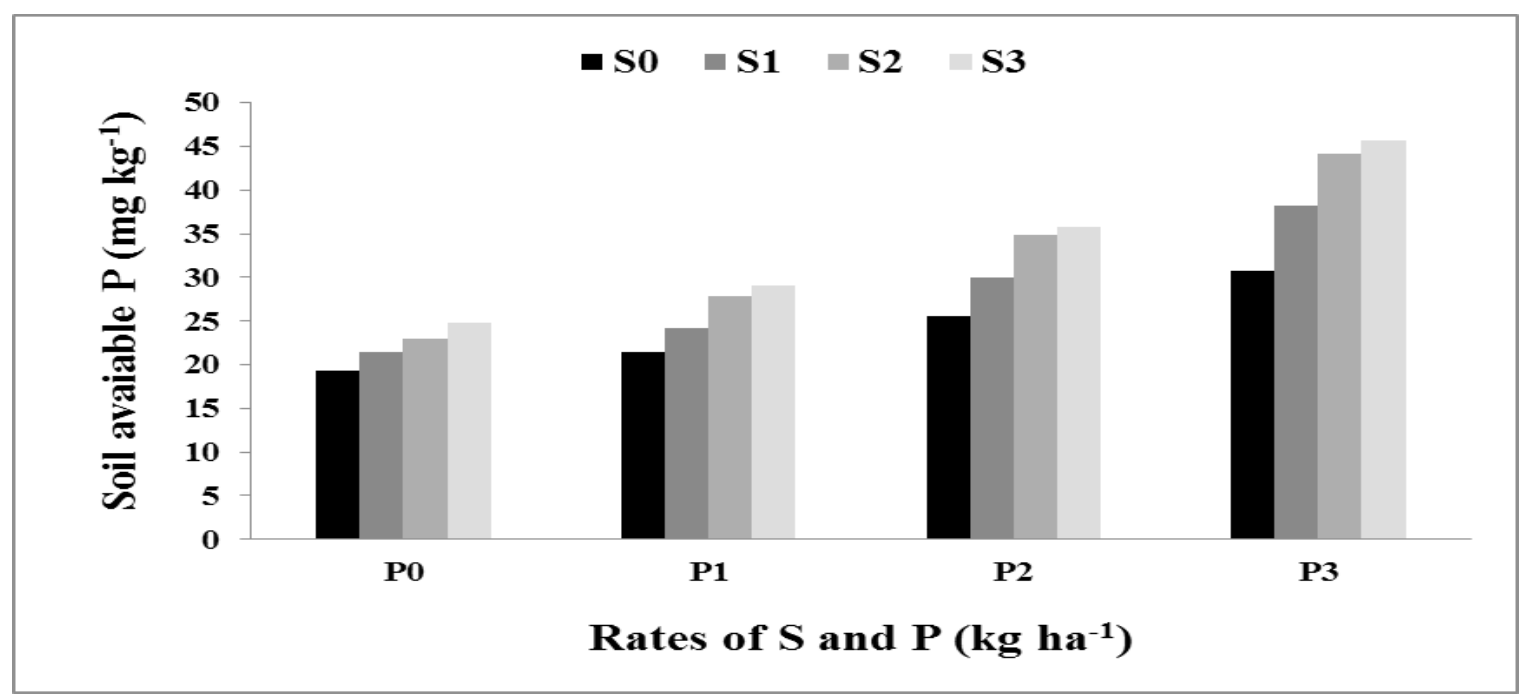

$\mathrm{S} 0=$ zero, $\mathrm{S} 1=119, \mathrm{~S} 2=238$ and $\mathrm{S} 3=357 \mathrm{~kg} \mathrm{ha}^{-1} . \mathrm{P} 1=238, \mathrm{P} 2=476$ and $\mathrm{P} 3=714 \mathrm{~kg}$ superphosphate $\mathrm{ha}^{-1}$.

LSD for available $\mathrm{P}=4.18$

Fig. 4. Soil available $P$ as affected by $S$ and $P$ fertilizers after harvesting soybean plants 


\section{Discussion}

The current study showed that application of $S$ and $P$ fertilizers and their combinations had significant and positive effects on all chosen parameters (branch number, pod number, plant height, nodules number, seeds and straw yields, oil and protein contents, nutrient concentrations, and soil available P). Moreover, soil $\mathrm{pH}$ also significantly influenced by $\mathrm{S}$ addition under all $\mathrm{P}$ rates. The high increases of the above-mentioned parameters after fertilizing the soil with $\mathrm{S}$ might be resulted from its significant role in decreasing soil $\mathrm{pH}$. This led to higher increases in nutrients availability and then enhanced the growth and yield of soybean. It was found by Kaya et al. (2009) that fertilizing soil with elemental S resulted a clear decreases in soil $\mathrm{pH}$ from 8.12 to 7.49 and 7.55 after harvesting bean and maize plants, respectively and this caused high enhancements in concentrations of nutrients $(\mathrm{N}$, $\mathrm{P}$ and $\mathrm{K}$ ) in the soil and plants. The initial decrease of soil $\mathrm{pH}$ might be ascribed to the release of $\mathrm{H}^{+}$ions from sulfuric acid during the microbial oxidation of S (Awad et al., 2011 and Sharma et al., 2014) Declining pH significantly improved the solubility and availability of soil nutrients, which might increase their absorptions by plants and finally enhance the plant yields. Similar results were obtained by Karimizarchi and Aminuddin (2014) where the increase in maize performance might be attributed to an increase in soil nutrient availability as a result of the moderate reduction in soil $\mathrm{pH}$. Moreover, they showed that the maximum maize performance (45.81 $\mathrm{g} \mathrm{pot}^{-1}$ ) occurred at soil $\mathrm{pH}$ of 6.29 after application of $0.5 \mathrm{~g} \mathrm{~S} \mathrm{~kg}^{-1}$.

The higher increases of protein contents in soybean seeds due to addition of $\mathrm{S}$ as compared with the control could be illustrated by their higher $\mathrm{N}$ concentrations (Table 4 ). The increase of protein contents after using $\mathrm{S}$ was resulted from increasing $\mathrm{N}$ amounts that are required for protein synthesis in soybean seeds (Sharma et al., 2014). Also, they mentioned that higher concentrations of $\mathrm{P}$ in the presence of $\mathrm{S}$ might be resulted from the high capacity of $S$ to increase soil available $\mathrm{P}$ and then improve its transferred to soybean seeds. The higher increase of soybean seeds that grown on a soil received $\mathrm{S}$ might be explained by the larger improvements of growth parameters such as plant height and pods number under these conditions. The results of this study are in agreements with Kaya et al. (2009) who showed that application of the elemental $\mathrm{S}$ positively affected $\mathrm{N}, \mathrm{P}$ and $\mathrm{K}$ concentrations of bean and maize plants in comparison with the control without S application. Significant changes were found in plant height and dry weight of garlic and they enhanced gradually with increasing $\mathrm{S}$ levels from 0 to $45 \mathrm{~kg} \mathrm{ha}^{-1}$ (Zaman et al., 2011). Moreover, the maximum plant height and dry weight $(71.5 \mathrm{~cm}$ and $4.20 \mathrm{~g})$ were recorded in plot fertilized with $45 \mathrm{~kg} \mathrm{~S}^{-1}$, whereas their lowest values $(44.3 \mathrm{~cm}$ and $1.73 \mathrm{~g}$ ) were found in control plots. It was indicated by Rajeswara et al., (2015) that $\mathrm{S}$ application at $40 \mathrm{~kg} \mathrm{ha}^{-1}$ increased the height of Palmarosa (Cymbopogon martiniias) and it ranged from $1.74-2.17 \mathrm{~m}$ with percentage increases of $18.4-40.0 \%$ over control. Moreover, they found that the biomass yield enhancements by $19.6-125.4 \%$ over the control.

\section{Conclusion}

Application of $\mathrm{S}$ with $\mathrm{P}$ not only improved growth parameters (pod and branch numbers and plant height) but also enhanced nutrient $(\mathrm{N}, \mathrm{P}$ and $\mathrm{K})$ concentrations and protein and oil contents. The combined additions of $\mathrm{S}$ and $\mathrm{P}$ at $238 \mathrm{~kg} \mathrm{ha}^{-1}$ and $476 \mathrm{~kg} \mathrm{ha}^{-1}$ in the form of elemental $\mathrm{S}$ and superphosphate could be highly recommended to enhance all studied parameters in the current investigation. The fertility of the chosen soil was highly improved through the increase of $\mathrm{P}$ availability, which was resulted from the decrease of $\mathrm{pH}$ values after application of the elemental $\mathrm{S}$. The present study provided clear evidence that the elemental $\mathrm{S}$ could be highly recommended as a useful and economical material to maintain the efficiency of superphosphate fertilizer in increasing growth and production of soybean plants in high pH clayey soils in Egypt.

\section{Acknowledgments}

The author is very grateful for the farmers in the experimental farm of Faculty of Agriculture, Benha University, Egypt for their great help in the management practices such as irrigation and harvest of soybean. Also, the author would like to send her deep thanks to the staff members of Soils and Water Department at Faculty of Agriculture, Benha University, Egypt (http:// www.fagr.bu.edu.eg and http://www.bu.edu.eg) for their helpful advice during the experimental work. 


\section{References}

Abdallah, M., Dubousset, L., Meuriot, F., Etienne ,P., Avice, J.C. and Ourry, A. (2010) Effect of mineral sulphur availability on nitrogen and sulphur uptake and remobilization during the vegetative growth of Brassica napus L. J. Exp. Bot. 61, 2635-2646.

A.O.A.C. (1995) "Association of Official Analysis Chemists. Official Methods of Analysis,'15Th ed. , Washington, D.C., U.S.A.

Awad, N.M., Abd El-Kader, A.A., Attia, M. and Alva, A.K. (2011) Effects of nitrogen fertilization and soil inoculation of sulfur-oxidizing or nitrogenfixing bacteria on onion plant growth and yield. Int. J. Agron.; doi:10.1155/2011/316856

Badawi, F.S.F., Biomy, A.M.M. and Desoky, A.H. (2011) Peanut plant growth and yield as influenced by co-inoculation with Bradyrhizobium and some rhizo-microorganisms under sandy loam soil conditions. Ann. Agric. Sci. 56, 17-25.

Balazs, H.,Opara-Nadib, O. and Beesea, F. (2005) A simple method for measuring the carbonate content of soil. Soil Sci.Am.J., 69,1066-1068,DOI:10.2136/ sssaj2004.0010.

Bhattacharjee, S., Singh, A.K., Kumar , M. and Sharma, S.K. (2013) Phosphorus, sulfur and cobalt fertilization effect on yield and quality of soybean (Glycine $\max$ L. Merrill) in acidic soil of Northeast India. Indian J. Hill Farm. 26, 63-66

Carsky, R.J., Singh, B.B. and Oyewole , R. (2001) Contribution of early-season cowpea to late season maize in the savanna zone of West Africa. Biol. Agric. Hort. 18, 303-315.

Chatterjee, C., Shukla, S. and Khurana, N. (1992) Effect of sulphur deficiency on metabolism of green gram (Phaseolus ratiatus). Indian J. Agric. Sci. 62, 445-449.

Darwesh, D.A., Maulood, P.M. and Amin, S.A. (2013) Effect of phosphorus fertilizers on growth and physiological phosphorus use efficiency of three soy bean cultivars. J. Agric. Vet. Sci. 3, 32-36.

Gyaneshwar ,P., Kumar, G.N., Parekh, L.J. and Poole, P.S. (2002) Role of soil microorganisms in improving P nutrition of plants. Plant and Soil, 245, 83-93.

Habtemichial , K.H., Singh , B.R. and Aune , J.B. (2007) Wheat response to N2 fixed by faba bean (Vicia faba L.) as affected by sulfur fertilization and rhizobial inoculation in semi arid Northern Ethiopia. J. Plant Nutr. Soil Sci. 170, 412-418.
Karimizarchi, M. and Aminuddin, H. (2014) Elemental sulphur application effects on nutrient availability and sweet maize (Zea mays L.) response in a high $\mathrm{pH}$ soil of Malaysia. Malaysian J. Soil Sci. 18, 75-86.

Kaya, M., Küçükyumuk, Z. and Erdal, I. (2009) Effects of elemental sulfur and sulfur-containing waste on nutrient concentrations and growth of bean and corn plants grown on a calcareous soil. Afr. J. Biotechnol. 8, 4481-4489.

Kravchenko, I., Kizilova, A., Titova, L., Iutinskaya, G.( 2013) Effect of microbial fertilizers on rhizospheric bacterial diversity and yield response of soybean plants. Agric. Sci. Dev. 2, 120-125.

Lepo , J.E. and Ferrenbach, S.M. (1990) "Measurement of nitrogen fixation by direct means", in "Methods for Evaluating Biological Nitrogen Fixation" (Ed. F. J. Bergersen), Jonhn Wiley \& Sons, Chichester. 67-111.

Macak , M. and Candrakova , E. (2013) The effect of fertilization on yield components and quality parameters of soybeans [(Glycine max (L.) Merr.] seeds. J. Central Eur. Agric. 14, 379-389.

Manesh, A.K., Armin, M. and Moeini, M.J. (2013) The effect of sulfur application on yield and yield components of corn in two different planting methods in saline conditions. Int. J. Agron. Plant Prod. 4,1474-1478.

Masuda, T. and Goldsmith, P.D. (2009) World soybean production: area harvested yield, and long-term projections. Int Food Agribus Manage Rev. 2009; 12,143-162.

Neilsen, D., Hogoe, L.K. and Hoyt, P.B. (1993) Oxidation of elemental sulphur and acidulation of calcareous orchard soils in southern British Colombia. Can. J. Soil Sci. 73, 103 -114.

Olsen, S.R. and Sommers, L.E. (1982) Phosphors. P.403-430.In A.L. Page (Ed), Methods of Soil Analysis, Am. Soc. Agron., Madison,WI, USA.

Page, A.I., Miller, R.H. and Keeney, D.R. (1982) Methods of Soil Analysis, part II. Chemical and Microbiological Methods, 2 nd ed., Amer. Soc. Agron., Madison, Wisconsin, USA.

Rahman, M.M., Bhuiyan, M.M.H., Sutradhar, G.N.C., Rahman, M.M. and Paul, A.K. (2008) Effect of phosphorus, molybdenum and rhizobium inoculation on yield and yield attributes of mungbean. J. Sustain. Crop Prod. 3, 26-33.

Rajeswara Rao, B.R., Rajput, D.K. and Patel, R.P. 
(2015) Improving yield and quality of palmarosa [Cymbopogon martinii (roxb.) wats. var. motiaburk. with sulfur fertilization. J. Plant Nutr. 38, 384-396.

Rowel, D.L. (1994) Soil Science: Methods and Applications. Longman Scientific and Technical. pp. 281-313.

Sadasivam, S. and Manickam, A. (1996) Biochemical Methods. New Age International Pvt. Ltd. Ansari Road, Daryaganj, New Delhi. 22-23.

Sandeep, R., Joseph, S., and Jisha, M.S. (2008) Yield and nutrient uptake of soybean as influenced by phosphate solubilising microorganisms. World J. Agric. Sci. 4, 835-838.

Schulze, J., Temple, G., Temple, S.J., Beschow „H. and Vance, C.P. (2006) Nitrogen fixation by white lupin under phosphorus deficiency. Ann. Bot. 98, 731- 740 .

Sharma, A., Sharma, S. and Gill, P.P.S. (2014) Influence of nitrogen and sulpher application on nutrient uptake, protein content and yield parameters of soybean. Indian J. Plant Sci. 3, 31-34.

Sheldrick, B.H. and Wang, C. (1993) Particle Size distribution. In: Soil Sampling and Methods of
Analysis, Ed.: Carter, M.R. Canadian Society of Soil Science, Lewis Publishers, Ann Arbor, MI. pp 499-511.

Snedecor, G. W. and Cocharn, W.G. (1991) Statistical Methods. 8th ed., lowa State Univ. Press, Lowa. USA.

Turan, M., Ataoglu, N. and Sahin, F. (2006) Evaluation of the capacity of phosphate solubilizing bacteria and fungi on different forms of phosphorus in liquid culture. J. Sustain Agri. 28, 99-108.

Yadav, H., Shekh, M.A., Takar, S.S. and Kherawat, B.S. (2013) Effect of phosphorus and sulphur on content, uptake and quality summer soybean. Int. J. Agric. Sci. 9, 91-94.

Zaman, M.S., Hashem, M.A., Jahiruddin, M. and Rahim, M.A. (2011) Effect of sulfur fertilization on the growth and yield of garlic (Allium sativum L.). Bangladesh J. Agril. Res. 36, 647-656.

\footnotetext{
كفاعة الكبريت العنصري والسماد الفوسفاتي في تحسين نمو نبات فول الصويا ومحصولة في ارض طينية$$
\text { قهم الار اضي وحمد السيا علي - كلية الزر اعة بمشتهر - جامعة بنها - مشتهر -طوخ - قليوبية - مصر. }
$$ 